\title{
SARS-CoV-2 Pandemic in Algeria
}

\author{
Samir Djemli, Abdelkrim Tahraoui, Mabrouk Boussena, Samia Messikh, Faiza Rouag, Ines Refes, Ibtissem \\ Chouba, Mohamed Kouadria and Rouya Memouni
}

Applied Neuroendocrinology Laboratory, Department of Biology, Faculty of Sciences; Badji Mokhtar Annaba University Algeria

"Corresponding authors

Samir Djemli, Applied Neuroendocrinology Laboratory, Department of Biology, Faculty of Sciences; Badji Mokhtar Annaba University Algeria

Submitted:05 March2021;Accepted:15 March2021;Published:22 March 2021

Citation: Samir Djemli, Abdelkrim Tahraoui, Mabrouk Boussena, Samia Messikh, Faiza Rouag, et al. (2021), SARS-CoV-2 Pandemic in Algeria. Medical \& Clinical Research 6(3): 461-463.

Keywords: Covid-19, Pandemic, Algeria, Coronavirus

\section{Editorial}

Coronavirus disease 2019 (COVID-19) is an infectious disease caused by a recently discovered coronavirus. The majority of people with COVID-19 will only experience mild or moderate symptoms and will recover without special treatment [1]. The virus that causes COVID-19 is spread primarily through droplets produced when an infected person coughs, sneezes, or breathes out. These droplets are too heavy to stay in the air and fall quickly to the ground or any nearby surface [2]. You can get infected by breathing in the virus, if you are near a sick person, or by touching a contaminated surface and then your eyes, nose or mouth.

The COVID-19 pandemic in Algeria is part of the worldwide andemic of coronavirus disease 2019 (COVID-19) caused by severe acute respiratory syndrome coronavirus 2 (SARS-CoV-2). The virus was confirmed to have spread to Algeria in February 2020 [3]. In December it was announced that Algeria will launch COVID-19 vaccinations in January 2021 [4]. On 25 February, Algeria laboratory-confirmed its first case of severe acute respiratory syndrome coronavirus 2 (SARS-CoV-2), an Italian man who arrived on 17 February; on 28 February, Algeria deported him back to Italy, via a special flight from Hassi Messaoud Airportwhere he was subject to quarantine $[5,6]$. On 2 March, Algeria confirmed two new cases of SARS-CoV-2, a woman and her daughter, the health ministry said.

Algeria has recorded 168 new cases of contamination with the Covid-19 coronavirus during the past 24 hours, an incidence rate of 0.4 per 100,000 inhabitants, the Ministry of Health reported this Thursday, March 4, 2021 [7]. The total number of people infected with the Covid-19 coronavirus in Algeria has reached 113,761. Algeria recorded 6 new deaths and 148 recoveries during the same period. 23 people are in intensive care. The total number of people who died has reached 3,002 and that of healings is 78,673. Algeria has decided to extend for fifteen (15) days the partial home confinement from 10 p.m. to 5 a.m. the next day in nineteen (19) wilayas of the country as of Tuesday, March 2 [8]. The decision is part of the system for managing the health crisis linked to the Coronavirus pandemic (Covid-19).

The partial home confinement measure from twenty-two (22) hours until the next day at five (5) a.m. is applicable in the following nineteen (19) wilayas Batna, Biskra, Blida, Bouira, Tebessa, Tlemcen, Tizi-Ouzou, Algiers, Jijel, Sidi Bel Abbes, Constantine, Mostaganem, M'sila, Oran, Boumerdes, El Tarf, Tissemsilt, Ain Temouchent and Relizane. The following thirty-nine (39) wilayas are not affected by the home confinement measure: Adrar, Chlef, Laghouat, Oum El Bouaghi, Bejaia, Béchar, Tamenghasset, Tiaret, Djelfa, Sétif, Saïda, Skikda, Annaba, Guelma, Médéa, Mascara, Ouargla, El Bayadh, Illizi, Bordj Bou Arréridj, Tindouf, El Oued, Khenchela, Souk Ahras, Tipaza, Mila, Ain Defla, Naâma, Ghardaia, Timimoun, Bordj Badji Mokhtar, Ouled Djellal, Beni Abbés, In Salah, In Guezzam, Touggourt, Djanet, El Meghaeir and El Meniaâ. Algeria has started its vaccination campaign with Sputnik-V as its effectiveness is questioned and its compatibility with Islamic precepts contested [1-9].

Among the population, skepticism is in order as soon as the arrival of the first batch is announced on January 28. Prime Minister Abdelaziz Djerad is therefore injected with the product in front of the cameras the day after the launch of the vaccination campaign against Covid-19, symbolically started in the wilaya of Blida, the first focus of the pandemic, on January 30 [10]. Algeria will receive in the coming days a donation of 200,000 doses of the Chinese Sinopharm vaccine, Chinese Ambassador to Algeria Li Lianhe told the official APS agency on Thursday. In addition, negotiations are underway for the manufacture in Algeria of the Russian Vaccine Sputnik V, according to the Algerian authorities [11]. 
Algiers launched its vaccination campaign on January 30 with a first batch of 50,000 doses of Sputnik V vaccine. Since then, it has also received a batch of 50,000 doses of the British vaccine AstraZeneca [1]. Some 111,500 contaminations, including nearly 3,000 deaths, have been officially recorded in Algeria since the census of the first case on February 25, 2020, according to the Ministry of Health. Russian Ambassador to Algeria Igor Beliaev said in an interview with Russian news agency Sputnik on Tuesday that "Russia is ready to produce its vaccine against Covid-19 'Sputnik V' in Algeria." This statement supports the remarks made last week by the Russian Minister of Health, Mikhail Murashko, during the presentation of the vaccine to the United Nations. The latter had indicated that his country "was going to produce the vaccine in Russia but also all over the world" [4]. The Russian vaccine in the name of "Sputnik V" developed by the Gamaleïa research center in Moscow, was the first anti-Covid-19 vaccine to be registered in the world. The efficacy of this vaccine has reached $95 \%$. Confirming that "it is one of the best vaccines on the market," said the ambassador [12].

For now, Algeria is following all the developments related to anticovid-19 vaccines, and will not yet provides a vaccine that is not approved by the World Health Organization (WHO), as stated several times. by the Algerian Minister of Health, Abderrahmane Benbouzid [8]. The Algerian Minister of Health has just announced that the vaccine against Covid-19 that the country is about to buy, will be dispensed free of charge. He also indicated that the scientific committee formed for this purpose has not yet decided on the choice of the vaccine to be acquired $[13,14]$. Finally, the minister confirmed that the necessary logistical means for all types of vaccines were in existence or in the study phase.

The English variant of Covid-19 was detected for the first time in Algeria, the Pasteur Institute of Algeria announced Thursday evening, confirming information from the French-speaking daily El Watan. "In line with the SARS-CoV-2 virus sequencing activities (...), the Institut Pasteur d'Algerie detected on positive PCRs, dated February 19, 2021, two British variants", indicated the institute in a press release [15].

"These two mutant strains were detected in a member of the health staff of the EHS of Psychiatry in Chéraga (currently isolated) and in an immigrant returning from France for his father's funeral," the statement said [7]. Without confirming the information from El Watan according to which the first two cases of the English variant of the coronavirus had appeared in Algeria, the Minister of Health, Abderrahmane Benbouzid wanted to be reassuring. "The variant is not a source of particular concern. Our experts are on the lookout for any eventuality of appearance of a variant," he said at a press conference, quoted by the official APS agency [6-8]. In order to prevent the arrival of variants on its territory, the Algerian government has decided to suspend all flights to Algeria during the month of March, according to information reported by local media and foreign diplomats but still not. officially confirmed. According to French Prime Minister Jean Castex, the English variant represents "about half" of the positive cases in France, where a large Algerian community lives [10].

In addition, Algeria received on Wednesday 200,000 doses of Sinopharm vaccine against Covid-19, a donation from China, a long-time partner of Algiers, according to APS. This delivery "comes to complete the device to fight against the pandemic", declared the spokesman of the government and Minister of Communication Ammar Belhimer on the arrival of this cargo Wednesday evening at the military airport of Boufarik in the west of France. "Alger. "This process will continue and there will be further deliveries of the anti-Covid-19 vaccine until the country's needs are fully met before the end of the year," Belhimer said [13]. Ideological allies after Algeria's independence in 1962, Beijing and Algiers have maintained close economic and trade relations since the 1990s.

At the start of the pandemic, China dispatched a team of virologists to Algeria and sent respirators and protective and screening equipment. This is the largest batch received by Algiers, which has received since the end of January two shipments of 50,000 doses of the Russian vaccine Sputnik V and another batch of 50,000 doses from the British-Swedish giant AstraZeneca [11]. Algeria should receive by the end of February a batch of 700,000 to 800,000 doses within the framework of the UN Covax system, according to the Minister of Health Abderahmane Benbouzid. According to the Director of Pharmacy at the Ministry of Health, Wahiba Hadjoudja, the most populous country in the Maghreb (44 million inhabitants) is also awaiting the arrival at the end of April of nine million doses from the African Institute for the prevention of epidemics, under the responsibility of the African Union [11-13].

In addition, negotiations are underway with Gamaleya, the Russian laboratory that produces Sputnik V, for the manufacture in Algeria of this vaccine, according to the Algerian authorities [14]. Algiers launched its vaccination campaign on January 30. More than 112,500 contaminations, including some 3,000 deaths, have been officially recorded in Algeria since the census of the first case on February 25, 2020, according to the latest report from the Ministry of Health.ç Discussions with the Russian partner for the production of the anti-Covid-19 vaccine "Sputnik V" are "very advanced", the two parties being on the verge of finalizing the project, the director of regulation at the ministry of Pharmaceutical Industry, Bachir Alouache. Speaking on the airwaves of the radio channel 1, Mr. Alouache indicated that the Ministry of the Pharmaceutical Industry had taken, "in application of the instructions of the President of the Republic during his last speech and of the Council of Ministers", all necessary measures and mobilized all material and human resources to facilitate the entry into service of the Russian vaccine production project Sputnik V [4].

He specified, in this context, that discussions with the Russian Fund for Direct Investments (RDIF) were "very advanced", in the sense that the two parties are working on examining the conditions for entry into service. of the Sputnik V vaccine production project in Algeria [6]. Assuring that Algeria was able to produce this vaccine in view of its experience in the matter and the number of laboratories it has, laboratories producing, he recalled, biotherapeutic products which use technologies similar to vaccine production technologies, the same speaker indicated the novelty for these laboratories lies in the technologies used in the production of the anti-Covid vaccine. $12 \mathrm{He}$ also noted the possibility of starting negotiations with the Chinese partner for the production of one of its anti-Covid vaccines. 
Regarding production methods, Mr. Alouache mentioned 4 stages of vaccine production. The first step, which concerns vital cells, more difficult because it requires cutting-edge technology, emphasizing that the Russian partner is committed to transferring it to Algeria $[15,16]$. The project will be located in Constantine, its realization could occur in two months According to the same official, Algeria is working to carry out the various stages of production locally, the "Saidal" Group having to take care of the first phase of production before involving the private laboratories in the operation thereafter, specifying that the ministry aims to achieve a stage of exporting to neighboring countries at a later stage [15]. Regarding the programmed quantity, Mr. Alouache explained that the main objective was to meet the needs of the national market, adding that the effective consecration of the production of the vaccine "Sputnik" could take place "in two months", and this, after import of raw materials and necessary equipment.

As for the production site, the same manager said it will be at the level of a unit under the Saidal group in Constantine.3 The President of the Republic, Mr. Abdelmadjid Tebboune had ordered, during the Council of Ministers which he chaired last Sunday, the continuation of the contacts with the Russian partner for the launch of the project of production of the Sputnik V vaccine in Algeria, in the shortest time possible [2, 3]. In addition, he gave instructions for the acceleration of "procedures to support investment in the pharmaceutical industry in order to achieve the stated objectives of reducing pharmaceutical imports by at least 400 million USD by the end of 2021, and to focus on export". In this regard, Mr. Alouache recalled that the national drug nomenclature has 3,600 drugs including 2,200 locally manufactured drugs, stressing that Algeria plans to produce value-added drugs that cost the public treasury colossal sums, like drugs for diabetes, blood diseases and cancer to reduce the import bill.ç

The reduction in the import bill is also achieved through the support of national production so that imports become complementary to national production, he added. About 29 drugs represent $50 \%$ of the budget of the Central Pharmacy of hospitals (drugs for diseases of diabetes, blood and cancer), he detailed, specifying that insulin represents $20 \%$ of the import bill and that Saidal is working to launch the project to produce the second generation of this drug in the coming months. The Ministry of Pharmaceutical Industry has 50 units reporting to private investors, including 29 units that will soon enter the production phase [5-7].

\section{References}

1. 1"Carte épidémiologique

https://web.archive.org/web/20200318221246/http:// covid19. sante.gov.dz/carte/.

2. "COVID-19 Map" (2021) https://coronavirus.jhu.edu/map. html. Johns Hopkins Coronavirus Resource Center.

3. "Algerian health minister confirms first COVID-19 case | Africa Times" (https://africatimes.com/2020/02/25/algerianhealth-minister-confirms-first-covid-19-case/). africatimes. com.

4. "Algeria to start Covid-19 vaccinations in January |Eyewitness News" https://ewn.co.za/2020/12/21/algeria-to-start-covid19-vaccinations-in-january.

5. Elsevier. "Novel Coronavirus Information Center" https:// www.elsevier.com/connect/coronavirus-information-center. Elsevier Connect.

6. Reynolds Matt (2020) "What is coronavirus and how close is it to becoming a pandemic?" https://www.wired.co.uk/article/ china-coronavirus. Wired UK.

7. "Crunching the numbers for coronavirus" https://www. imperial.ac.uk/news/196137/crunching-numberscoronavirus/. Imperial News.

8. "High consequence infectious diseases (HCID); Guidance and information about high consequence infectious diseases and their management in England" https://www.gov.uk/guidance/ high-consequence-infectious-diseases-hcid. GOV.UK.

9. "World Federation Of Societies of Anaesthesiologists Coronavirus" https://www.wfsahq.org/resources/coronavirus.

10. “COVID-19: Carte épidémiologiqueRachid Rouabhi” (https:// web.archive.org/web/20200401210617/http://covid19.sante. gov.dz/carte/.

11. Algérie Presse Service (APS) (2020) Covid-19: hausse sensible du nombre de tests quotidiens dans les laboratoires de l'IPA. Consulté sur: http://www.aps.dz/sante-sciencetechnologie/104593-covid-19-hausse-sensible-du-nombrede-tests-quotidiens-dans-les-laboratoires-de-l-ipa.

12. Benrahal N (2020) Prise en charge médicale du Coronavirus: Les établissements publics de santé s'adaptent à l'urgence, El Moudjahid, quotidien national d'information. Consulté sur: http://www.elmoudjahid.com/fr/actualites/150532.

13. Gilbert M, Pullano G, Pinotti F, Valdano E, Poletto C, et al. (2020) Preparedness and vulnerability of African countries against importations of COVID-19: a modelling study In The Lancet 395: 871-877.

14. Hamra F (2020) Pénurie de 10 médicaments pour maladies chroniques: A qui la faute?. CAP Ouest. Consulté sur: http:// capouest.info/2020/02/17/penurie-de-10-medicaments-pourmaladies-chroniques.

15. Messaili M, Kaïd Tlilane N (2017) Dépenses publiques de santé et santé de la population en Algérie : une analyse économétrique. In Santé Publique 29 : 383-392.

16. MSPRH DGPPS (2020) "Plan de préparation et de riposte à la menace de l'infection coronavirus Covid-19". Disponible sur: http://www.sante.gov.dz/images/Prevention/cornavirus/ Plan-de-prparation.pdf.
Copyright: (02021 Samir Djemli, et al. This is an open-access article distributed under the terms of the Creative Commons Attribution License, which permits unrestricted use, distribution, and reproduction in any medium, provided the original author and source are credited. 